Meta

Journal des traducteurs

Translators' Journal

\title{
Teaching Interpreting by Distance Mode: An Empirical Study
}

\section{Leong Ko}

Volume 53, numéro 4, décembre 2008

URI : https://id.erudit.org/iderudit/019649ar

DOI : https://doi.org/10.7202/019649ar

Aller au sommaire du numéro

\section{Éditeur(s)}

Les Presses de l'Université de Montréal

ISSN

0026-0452 (imprimé)

1492-1421 (numérique)

Découvrir la revue

Citer cet article

Ko, L. (2008). Teaching Interpreting by Distance Mode: An Empirical Study. Meta, 53(4), 814-840. https://doi.org/10.7202/019649ar

\section{Résumé de l'article}

Cet article se fonde sur une étude empirique de l'enseignement à distance de l'interprétation de liaison, plus précisément l'interprétation de dialogue, l'interprétation consécutive et la traduction à vue. Pour cette recherche, nous avons recruté deux groupes d'étudiants : un groupe expérimental, qui devait être formé à distance, et un groupe contrôle, formé selon le mode face à face. Le stage de formation était d'une durée de 39 heures, c'est-à-dire de 13 semaines à raison de 3 heures de contact par semaine. La formation a suivi le principe selon lequel aucun contact face à face avec les étudiants à distance ne devait se produire pendant le stage, y compris à l'examen. Les principaux médias employés dans le cadre de la recherche étaient les téléconférences non visuelles, le téléphone et l'Internet. Les compétences des étudiants en interprétation, dont le transfert linguistique et les compétences paralinguistiques, ont été évaluées par des épreuves variées, y compris une épreuve indépendante de niveau national. Les résultats de cette recherche indiquent que les étudiants formés à distance sont capables d'atteindre un niveau de compétences et d'habiletés, pour l'interprétation, égal ou comparable à celui qui a été atteint par les étudiants formés selon le mode face à face. Cette recherche a des implications pédagogiques pour de futurs projets dans le domaine du téléenseignement de l'interprétation.
Tous droits réservés @ Les Presses de l’Université de Montréal, 2008
Ce document est protégé par la loi sur le droit d'auteur. L’utilisation des services d'Érudit (y compris la reproduction) est assujettie à sa politique d'utilisation que vous pouvez consulter en ligne.

https://apropos.erudit.org/fr/usagers/politique-dutilisation/ 


\title{
Teaching Interpreting by Distance Mode: An Empirical Study
}

\author{
LEONG KO \\ The University of Queensland, Brisbane, Australia \\ 1.ko@uq.edu.au
}

\section{RÉSUMÉ}

Cet article se fonde sur une étude empirique de l'enseignement à distance de l'interprétation de liaison, plus précisément l'interprétation de dialogue, l'interprétation consécutive et la traduction à vue. Pour cette recherche, nous avons recruté deux groupes d'étudiants: un groupe expérimental, qui devait être formé à distance, et un groupe contrôle, formé selon le mode face à face. Le stage de formation était d'une durée de 39 heures, c'est-à-dire de 13 semaines à raison de 3 heures de contact par semaine. La formation a suivi le principe selon lequel aucun contact face à face avec les étudiants à distance ne devait se produire pendant le stage, y compris à l'examen. Les principaux médias employés dans le cadre de la recherche étaient les téléconférences non visuelles, le téléphone et l'Internet. Les compétences des étudiants en interprétation, dont le transfert linguistique et les compétences paralinguistiques, ont été évaluées par des épreuves variées, y compris une épreuve indépendante de niveau national. Les résultats de cette recherche indiquent que les étudiants formés à distance sont capables d'atteindre un niveau de compétences et d'habiletés, pour l'interprétation, égal ou comparable à celui qui a été atteint par les étudiants formés selon le mode face à face. Cette recherche a des implications pédagogiques pour de futurs projets dans le domaine du téléenseignement de l'interprétation.

\section{ABSTRACT}

This paper is based on an empirical study of teaching liaison interpreting - specifically, dialogue interpreting, consecutive interpreting and sight translation - by distance mode. In this research, two groups of students were recruited - the experimental group to be taught by distance mode and a control group trained face-to-face. The training program lasted for 13 weeks or 39 hours, with three contact hours per week. The training followed the principle that no face-to-face contact with distance students was made during the training process, including the final examination. The major media used in the research included sound-only teleconferencing, telephone and the Internet. Students' interpreting skills including language transfer and paralinguistic skills were assessed in different tests including an independent national test. The results of the research indicate that students trained by distance mode can achieve a level similar or comparable to those trained in the face-to-face manner in terms of interpreting ability and skills. The research has generated pedagogical implications for future attempts to teach interpreting by distance mode.

\section{MOTS-CLÉS/KEYWORDS}

teleconferencing, liaison interpreting, off-campus, on-campus, teaching interpreting

\section{Introduction}

There have been a number of attempts to teach interpreting by distance mode, such as those at Vancouver Community College in Canada (Carr and Steyn 2000), the University of South Africa (Moeketsi and Wallmach 2005), Adelaide Institute of 
Training and Further Education in Australia (Rowan 1998), the University of Geneva (2005), and Language Line Services of AT\&T in the United States (Language Line Services 2004). However, all of these attempts still retain many features of conventional face-to-face teaching or guided self-study, without providing enough opportunities for interactive interpreting practice comparable to classroom learning, or are merely workshops designed for practicing interpreters, and therefore have not dealt adequately with the critical issue of teaching interpreting per se by distance mode (Ko 2006a).

An interpreting program normally consists of core interpreting subjects and interpreting-related subjects: the former relate to interpreting per se, e.g., dialogue interpreting and consecutive interpreting, while the latter support the acquisition of techniques and knowledge of interpreting, such as professional knowledge and interpreting theory (Ko 2006a). Due to the interactive nature of interpreting, teaching interpreting per se is the key challenge in any attempt to teach interpreting by distance mode.

This paper focuses only on teaching liaison interpreting. Liaison interpreting refers to the type of interpreting that is usually performed in the consecutive mode in two language directions by the same person, and is widely used where two or more interlocutors do not share a language and an interpreter must be present to bridge the communication gap (Gentile et al. 1997: 1 and 17).

This research uses the telephone (including the sound-only teleconferencing facility) as the main medium in teaching interpreting by distance mode, supplemented by other equipment. This is because the telephone is one of the simplest, most popular and convenient, and most cost effective distance learning technologies that can accommodate effective interactive communication (e.g., U.S. Department of Health and Human Services 2001; Fors 1999; Ko 2006). Furthermore, the telephone has been used for providing interpreting services in many countries (Pointon et al. 1998; Ko 2006a) as well as for conducting interpreting workshops (e.g. Language Line Services 2004).

The research is based on a 13-week empirical study in which two groups of students were trained - one by distance mode and the other in the conventional faceto-face manner. The underlying principle in teaching distance students is that no face-to-face contact is allowed throughout the training process, including pre-training selection and the final examination. This study was designed to tackle the issues of teaching dialogue interpreting, consecutive interpreting and sight translation by distance mode as these are the three most common forms of liaison interpreting. The aims of the study were to investigate:

1. feasibilities and strategies for training interpreters by distance mode;

2. whether students trained by distance mode could achieve a level similar or comparable to that of on-campus students in terms of interpreting ability and skills, provided that the same general approach was followed with special strategies adopted to address mode-specific issues in training;

3. how technologies affect teaching and learning by distance mode;

4. whether interpreters trained by distance mode might demonstrate a narrower range of interpreting skills, for instance demonstrating ability only in the medium(s) used in training; and

5. the workload and costs involved in running a distance interpreting program using the technologies specified in this research.

In this research, the author was both the researcher and teacher. 


\section{Program design}

For the purpose of this research, a training program was developed and two groups of students were recruited - one as the off-campus group (the test group) to be taught by distance mode, and the other as an on-campus group (the control group) taught in a language laboratory. The number of students in each group was seven, because the telecommunications facility available for this research could only accommodate eight participants including the teacher. The content of the teaching and the amount of practice for the two groups was identical but the modes of delivery and technologies used were different. The pair of languages in the teaching experiment was English and Chinese Mandarin. The duration of the training program was 13 weeks, consisting of three hours of teaching and one hour of homework per week for each group. The venue for the on-campus teaching was Deakin University, Burwood Campus in Melbourne, Australia (the university where the author worked at the time of the research). For the off-campus teaching, the teacher was in his office and the students in their nominated place of study with access to the telephone and the Internet. No face-to-face contact with off-campus students was made during the training process including student selection and the final examination.

The students were recruited in Australia. Applicants were required to pass a screening test to ensure that they had sufficient bilingual competence to undertake training at the level of the program. It was specified that candidates must not have received any interpreting training or participated in any distance training program via teleconferencing before. Once the quota was filled, no further applications were considered. Of the seven students accepted for off-campus study, two lived in Melbourne, three in Sydney (about 1,000 km from Melbourne) and one in Perth (around 4,000 km from Melbourne and Sydney, with a two-hour time difference). The on-campus students were all in Melbourne.

\subsection{Equipment}

The main equipment used by the teacher in teaching the two groups is shown in Table 1.

TABLE 1

Main equipment used for teaching

\begin{tabular}{|l|l|l|}
\hline Equipment & Off-campus & On-campus \\
\hline Teleconferencing and Polycom & Yes & No \\
\hline Spare telephone line or mobile phone & Yes & No \\
\hline Language laboratory & No & Yes \\
\hline Cassette tape player & Yes & Yes (built into the lab) \\
\hline Cassette tape recorder & Yes & Yes (built into the lab) \\
\hline Video player & No & Yes (built into the lab) \\
\hline $\begin{array}{l}\text { Computer with Windows 95 or above with } \\
\begin{array}{l}\text { Chinese software (or fax machine) and access to } \\
\text { the Internet and e-mail }\end{array}\end{array}$ & Yes & Optional \\
\hline
\end{tabular}


Teleconferencing refers here to a sound-only telephone facility whereby a number of participants can be connected into the telephone for a conference. There are other types of teleconferencing facilities that may accommodate more than eight participants (e.g., Intercall Australia Pty Ltd 2006; Telstra 2006). The Polycom is a hands-free telephone set that is connected to the telephone line and enables the user to talk and listen to students via a loudspeaker. A spare telephone line or a mobile phone was used as a standby, in case a student who arrived late or was disconnected during class could ring the teacher for connection or reconnection. A computer with Chinese software and access to the Internet and e-mail was necessary for both teaching and communication purposes. A fax machine provided the teacher with an alternative way to send materials to the students who also had a fax machine.

The equipment used by the students in each group is listed in Table 2.

TABLE 2

Equipment used by students in each group

\begin{tabular}{|l|l|l|}
\hline Equipment & Off-campus & On-campus \\
\hline $\begin{array}{l}\text { Speakerphone or telephone with headphones, } \\
\text { capable of three-way conversations }\end{array}$ & Yes & No \\
\hline Cassette tape player & Yes & Yes \\
\hline Cassette tape recorder & Yes & Yes \\
\hline Video player & Yes & Yes \\
\hline $\begin{array}{l}\text { Computer with Windows 95 or above with Chinese } \\
\text { software and access to the Internet and e-mail }\end{array}$ & Yes & Optional \\
\hline Fax machine & Optional & No \\
\hline
\end{tabular}

A speakerphone is a hands-free telephone set. Either a speakerphone or a telephone with headphones is suitable. The students' telephone line had the function of three-way conversations - i.e., three people in different places could be connected - so that three students could practice dialogue interpreting over the telephone. This function is provided by telephone companies such as Telstra (2006) and Optus (2006) free of charge in Australia, but users have to pay for the telephone calls at standard rates.

\subsection{Level and content of training}

The level of training was based on the requirements of the National Accreditation Authority for Translators and Interpreters (NAATI) in Australia for Interpreter (formerly known as Level Three) and an additional requirement regarding paralinguistic skills. Specifically, at the end of the training program, the students were expected to be able to:

1. interpret dialogues of approximately 400 English words or equivalent in each dialogue with a single segment not exceeding 60 words;

2. interpret consecutive passages of approximately 300 English words or equivalent in Mandarin; and

3. demonstrate satisfactory face-to-face communication and paralinguistic skills in interpreting, such as management of interpreting situations, and maintaining appropriate body language and eye contact. 
The first two requirements are set down by NAATI (NAATI 2002: 24-25) in its Interpreter test. Interpreters are required to interpret accurately using the appropriate style and register. The third is not one of NAATI's requirements, but is a common expectation in real face-to-face interpreting (e.g., Wadensjö 1992; Gentile et al. 1996; Ko and Lin 1996; Ko 1998; Roy 2000; Riccardi 2002). It is also an important element in distance teaching and was therefore included in this program.

The content of the training program mainly consisted of core interpreting subjects - i.e., dialogue interpreting, consecutive interpreting and sight translation. Sight translation is not included in the current NAATI Interpreter test and was not an assessment item in this program, but it is a necessary skill for liaison interpreters and is considered important in developing students' language transference skills, especially in the initial stages of interpreting (e.g., Weber 1990; Ko and Lin 1996; May 1996; Kuwahata-Rich and Sayeg 1997). Sight translation can take different forms depending on the needs. For instance, in the setting of international conferences, interpreters who work in the booth may sight translate a speech simultaneously when it is being delivered by a speaker. However, in this program, sight translation was designed in the way where students were given a written text to read for a couple of minutes and then render into the other language orally, because this is a popular form of sight translation in liaison interpreting. The program also contained some essential interpreting-relevant components such as the principles of interpreting, interpreting theory, communication skills, memory and note-taking skills, and paralinguistic skills. Finally, the program included weekly interpreting homework.

\subsection{Delivery of the program}

The following table shows how the different components of the program were delivered to the two groups. Many of these types of interpreting practice are used in interpreting programs in Australia. An explanation of some major items is provided in the following subsections.

TABLE 3

Delivery of the training program

\begin{tabular}{|l|l|l|}
\hline Item & Off-campus & On-campus \\
\hline $\begin{array}{l}\text { Lecture } \\
\text { - Multiple group practice }\end{array}$ & Via teleconferencing & $\begin{array}{l}\text { Face-to-face teaching in the } \\
\text { language laboratory }\end{array}$ \\
$\begin{array}{l}\text { - Whole class practice by } \\
\text { listening to audio tapes of } \\
\text { pre-recorded dialogues } \\
\text { telephone }\end{array}$ & - Via teleconferencing & $\begin{array}{l}\text { - Face-to-face practice in the } \\
\text { lab } \\
\text { - Practice in the lab using } \\
\text { headphones }\end{array}$ \\
\hline $\begin{array}{l}\text { Consecutive interpreting } \\
\text { - Whole class practice }\end{array}$ & - Via teleconferencing & $\begin{array}{l}\text { - Practice in the lab using } \\
\text { headphones } \\
\text { - Face-to-face practice or as } \\
\text { otherwise arranged by the } \\
\text { students }\end{array}$ \\
\hline
\end{tabular}




\begin{tabular}{|c|c|c|}
\hline $\begin{array}{l}\text { Sight translation } \\
\text { - Whole class practice } \\
\text { - Pair practice }\end{array}$ & $\begin{array}{l}\text { - Via teleconferencing } \\
\text { - Practice by telephone }\end{array}$ & $\begin{array}{l}\text { - Practice in the lab using } \\
\text { headphones } \\
\text { - Face-to-face practice or as } \\
\text { otherwise arranged by the } \\
\text { students }\end{array}$ \\
\hline Consultation & $\begin{array}{l}\text { Via First Class through the } \\
\text { Internet, supplemented by } \\
\text { telephone }\end{array}$ & $\begin{array}{l}\text { Face-to-face consultation, } \\
\text { supplemented by telephone }\end{array}$ \\
\hline $\begin{array}{l}\text { Provision of materials to } \\
\text { students } \\
\text { - Printed materials } \\
\text { - Audio and video tapes }\end{array}$ & $\begin{array}{l}\text { - Sent by mail/e-mail/ } \\
\text { Bulletin Board of First } \\
\text { Class/fax (optional) } \\
\text { - Sent by mail }\end{array}$ & $\begin{array}{l}\text { - Distributed in class } \\
\text { - Distributed in class }\end{array}$ \\
\hline $\begin{array}{l}\text { Type of interpreting home- } \\
\text { work: } \\
\text { - Dialogue topic } \\
\text { - Scripted dialogue } \\
\text { - Written dialogue scenario } \\
\text { - Audio-taped dialogue } \\
\text { - Audio-taped speech } \\
\text { - Video-taped speech } \\
\text { - Live speech }\end{array}$ & $\begin{array}{l}\text { Distributed and collected by } \\
\text { mail }\end{array}$ & $\begin{array}{l}\text { Distributed and collected in } \\
\text { class }\end{array}$ \\
\hline $\begin{array}{l}\text { Communication outside } \\
\text { teaching hours } \\
\text { - Teacher-student communi- } \\
\text { cation } \\
\text { - Student-student communi- } \\
\text { cation }\end{array}$ & $\begin{array}{l}\text { - E-mail/mail/telephone } \\
\text { - E-mail/telephone/Chat } \\
\text { Room of First Class }\end{array}$ & $\begin{array}{l}\text { - E-mail/telephone/face-to- } \\
\text { face communication } \\
\text { - To be decided by students }\end{array}$ \\
\hline
\end{tabular}

\subsubsection{Dialogue interpreting}

"Multiple group practice" refers to practice in which the class was divided into groups of three students. One participant acted as the English speaker, one as the Mandarin speaker, and another as the interpreter, to simulate real dialogue interpreting. The interpreting materials included dialogue topics, scripted dialogues and written dialogue scenarios. The students took turns to play the speakers' roles and interpret. All groups practiced dialogue interpreting concurrently. The teacher could participate in a group either as a speaker or an observer, and provide feedback on students' performance at the end of the practice.

"Whole class practice by listening to audio tapes of pre-recorded dialogues" refers to practice whereby the teacher played an audio tape of pre-recorded dialogues in class and all students interpreted at the same time after a segment of dialogue was played. This is similar to the NAATI dialogue interpreting test in which a prerecorded tape is used (NAATI 2002).

\subsubsection{Consecutive interpreting}

"Whole class practice" refers to practice in which all students interpreted at the same time after a segment of speech or a passage was delivered. When students finished 
interpreting, another segment or passage was delivered. Speeches were either live or recorded, and interpreting was mainly in one language direction. Discussion was held at the end of the practice session.

"Pair practice" refers to practice in which two students worked together, taking turns to deliver passages and interpret, and then having a discussion between themselves. The teacher rotated the students in pairs and provided passages for interpreting. This method was used for homework in this program.

\subsubsection{Sight translation}

"Whole class practice" refers to practice in which all students performed sight translation at the same time. The students were given a copy of an article or document to peruse briefly before rendering it into the other language. "Pair practice" is similar to that in consecutive interpreting - i.e., one student sight translated a passage to the other student and vice versa. This was also only used for homework.

\subsubsection{Consultation}

A weekly one-hour consultation was made available to students in both groups. In the off-campus mode, the consultation was provided via First Class, which is a textbased synchronous communication network on the Internet. It is capable of processing messages in the Chinese language, provided the participants have Chinese software on their computers. Now a new system with more functions known as "Blackboard" has replaced First Class. The off-campus students could also ring the teacher. In the on-campus mode, the consultations took place in the teacher's office, but the students could also ring the teacher during the consultation hour.

\subsubsection{Interpreting homework}

The purposes of interpreting homework were to keep the students in regular practice and to encourage peer learning. Students were required to do weekly interpreting homework in the forms of pair practice, group practice and individual practice. The materials included text materials and pre-recorded audio and video tapes provided by the teacher. Students were required to record their interpreting practice on an audio tape and submit it to the teacher for checking.

\subsection{Assessment}

There were three major assessments to evaluate the effectiveness of the training - a pre-training test, a final examination and an additional live dialogue interpreting test. With NAATI's permission, NAATI sample tests were used. In addition, five students in each group sat the independent national NAATI Interpreter Test after the training.

The pre-training test consisted of one dialogue and two consecutive interpreting passages (one in each language direction). It was administered at the beginning of the program to collect data about students' initial level of competence in interpreting. The students' interpreting was audio recorded and marked by two independent 
examiners with accreditation at NAATI Level Three (Mandarin), which is NAATI's normal practice (1997) for marking interpreting tests. The final examination using a different set of NAATI sample tests was conducted at the end of the training program using the same methods, and was marked by the same two examiners in order to ensure consistency. The examination was conducted via teleconferencing for the off-campus students, and face-to-face for the on-campus students.

At the end of the training, the students in both groups sat an additional live face-to-face dialogue interpreting test, in which two speakers delivered a dialogue in a conversational manner. One speaker was the teacher and the other was from outside the program. The purpose of this test was to assess the students' paralinguistic skills and see whether those trained by distance mode could demonstrate the interpersonal communication skills required in face-to-face interpreting. This was the first and last time the teacher and students met face-to-face during the program. The test was video taped but was not marked by external examiners. It was analyzed by the researcher for the above purpose.

The pass mark required by NAATI is 70\% (NAATI 1997). Since there were only one dialogue and two consecutive interpreting passages in the pre-training test and final examination, proportionally a pass required:

- $17.5 / 25$ for one dialogue, equivalent to $70 \%$

- $21 / 30$ for two consecutive interpreting passages, equivalent to $70 \%$

- 38.5/55 for overall mark, equivalent to $70 \%$

Paralinguistic skills are not assessed in the NAATI test, so in the additional dialogue interpreting test the following assessment guidelines from the former interpreting program at Deakin University, Australia were used:

- Seeking clarification in an inappropriate way;

- managing the interpreting situation inappropriately, including handling interruptions and curtailing speakers;

- demonstrating inappropriate public speaking skills;

- demonstrating inappropriate body language and maintaining an inappropriate level of eye contact (Deakin University 1996).

\section{Data collection}

Data was collected from the following seven sources:

1. Pre-training test;

2. final examination;

3. additional live face-to-face dialogue interpreting test;

4. results of the NAATI test from five students in each group;

5. students' weekly diaries;

6. teacher's weekly diaries;

7. end-of-program questionnaire and interview.

\section{Findings and discussions}

The major findings of this experiment are discussed under the following six headings: students' achievements; results of the NAATI test; technical points; pedagogical issues; teaching workload; and cost effectiveness. Other findings that are not directly relevant to this paper are not outlined here. 


\subsection{Students' achievements}

The students' achievements were measured by the pre-training test, final examination and independent NAATI test. The results of the pre-training test show that none of the students in either group scored a minimum of $38.5 / 55$ or $70 \%$ required to pass the equivalent NAATI Interpreter test. Six students in the off-campus group (85.7\%) and five in the on-campus group (71.4\%) abandoned the test in the middle of consecutive interpreting in one or both language directions. The following tables show the final results for the pre-training test for the two groups after averaging the marks given by the two examiners. Students are represented by alphabetical letters that will remain unchanged throughout the paper. Marks are also given in percentages.

TABLE 4

Results of pre-training test (off-campus group)

\begin{tabular}{|l|l|l|l|l|l|}
\hline Student & $\begin{array}{l}\text { Dialogue } \\
\text { /25 }\end{array}$ & $\begin{array}{l}\text { English Passage } \\
/ 15\end{array}$ & $\begin{array}{l}\text { Mandarin } \\
\text { Passage } / 15\end{array}$ & $\begin{array}{l}\text { Total } \\
/ 55\end{array}$ & $\begin{array}{l}\text { Result } \\
\text { Pass/Fail }\end{array}$ \\
\hline A & $14=56 \%$ & $6.8=45.3 \%$ & $5=33.3 \%$ & $25=45.5 \%$ & Fail \\
\hline B & $13.3=53.2 \%$ & $6.8=45.3 \%$ & $4.5=30 \%$ & $24.5=44.5 \%$ & Fail \\
\hline C & $13=52 \%$ & $7.3=48.7 \%$ & $4=26.7 \%$ & $24.3=44.2 \%$ & Fail \\
\hline D & $12.3=49.2 \%$ & $7=46.7$ & $4.8=32 \%$ & $24=43.6 \%$ & Fail \\
\hline E & $11=44 \%$ & $6.3=42 \%$ & $5.3=35.3 \%$ & $22.5=40.9 \%$ & Fail \\
\hline F & $11.8=47.2 \%$ & $3.5=23.3 \%$ & $4.3=28.7 \%$ & $19.5=35.5 \%$ & Fail \\
\hline G & $11=44 \%$ & $4.3=28.7 \%$ & $3.8=25.3 \%$ & $19=34.5 \%$ & Fail \\
\hline $\begin{array}{l}\text { Group } \\
\text { average }\end{array}$ & $49.4 \%$ & $40 \%$ & $30.2 \%$ & $41.2 \%$ & \\
\hline
\end{tabular}

TABLE 5

Results of pre-training test (on-campus group)

\begin{tabular}{|l|l|l|l|l|l|}
\hline Student & $\begin{array}{l}\text { Dialogue } \\
\text { /25 }\end{array}$ & $\begin{array}{l}\text { English Passage } \\
/ 15\end{array}$ & $\begin{array}{l}\text { Mandarin } \\
\text { Passage } / 15\end{array}$ & $\begin{array}{l}\text { Total } \\
/ 55\end{array}$ & $\begin{array}{l}\text { Result } \\
\text { Pass/Fail }\end{array}$ \\
\hline A & $15.3=61.2 \%$ & $7.8=52 \%$ & $6.8=45.3 \%$ & $29.8=54.2 \%$ & Fail \\
\hline B & $16.3=65.2 \%$ & $5.5=36.7 \%$ & $5.5=36.7 \%$ & $27.3=49.6 \%$ & Fail \\
\hline C & $15.3=61.2 \%$ & $5.3=35.3 \%$ & $5=33.3 \%$ & $25.5=46.4 \%$ & Fail \\
\hline D & $12=48 \%$ & $7.3=48.7 \%$ & $5.3=35.3 \%$ & $24.5=44.5 \%$ & Fail \\
\hline E & $12.5=50 \%$ & $6=40 \%$ & $5.3=35.3 \%$ & $23.8=43.3 \%$ & Fail \\
\hline F & $11=44 \%$ & $5.3=35.3 \%$ & $4.8=32 \%$ & $21=38.2 \%$ & Fail \\
\hline G & $11=44 \%$ & $5.3=35.3 \%$ & $4=26.7 \%$ & $20.3=36.9 \%$ & Fail \\
\hline $\begin{array}{l}\text { Group } \\
\text { average }\end{array}$ & $53.4 \%$ & $40.5 \%$ & $34.9 \%$ & $44.7 \%$ & \\
\hline
\end{tabular}

For comparison purposes, the overall marks of each student in both groups are shown in the following table with the highest marks of the students in both groups shown first. 
TABLE 6

Results of pre-training test

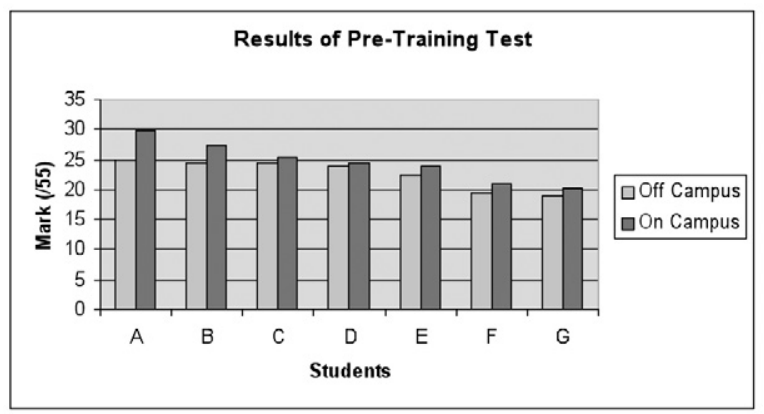

The three tables show that the students in both groups had similar levels of interpreting competence, but the level of the on-campus students was slightly higher than that of the off-campus students. It was later found that the off-campus students' lower level of interpreting performance was caused by factors such as improper telephone equipment, lack of experience in working with the telephone, and poor concentration over the telephone, which will be discussed later in the paper.

At the end of the program, four off-campus students (57.1\%) passed the final examination and no student abandoned the examination. One student scored a borderline mark of $69.1 \%$. In the on-campus group, three students (42.9\%) passed the examination and no student abandoned the examination. One student received a borderline mark of $68.2 \%$. The results of the two groups are shown in the following two tables, with the results of the pre-training test in brackets for comparison.

TABLE 7

Results of final examination (off-campus group)

\begin{tabular}{|l|l|l|l|l|l|}
\hline Student & $\begin{array}{l}\text { Dialogue } \\
/ 25\end{array}$ & $\begin{array}{l}\text { English Passage } \\
/ 15\end{array}$ & $\begin{array}{l}\text { Mandarin } \\
\text { Passage } / 15\end{array}$ & $\begin{array}{l}\text { Total } \\
/ 55\end{array}$ & $\begin{array}{l}\text { Result } \\
\text { Pass/Fail }\end{array}$ \\
\hline A & $\begin{array}{l}19(14) \\
=76 \%(56 \%)\end{array}$ & $\begin{array}{l}8.5(6.8) \\
=56.7 \%(45.3 \%)\end{array}$ & $\begin{array}{l}10.5(5) \\
=70 \%(33.3 \%)\end{array}$ & $\begin{array}{l}38(25) \\
=69.1 \%(45.5 \%)\end{array}$ & Fail \\
\hline B & $\begin{array}{l}21.5(13.3) \\
=86 \%(53.2 \%)\end{array}$ & $\begin{array}{l}12.5(6.8) \\
=83.3 \%(45.3 \%)\end{array}$ & $\begin{array}{l}11.5(4.5) \\
=76.7 \%(30 \%)\end{array}$ & $\begin{array}{l}45.5(24.5) \\
=82.7 \%(44.5 \%)\end{array}$ & Pass \\
\hline C & $\begin{array}{l}21.5(13) \\
=86 \%(52 \%)\end{array}$ & $\begin{array}{l}10.5(7.3) \\
=70 \%(48.7 \%)\end{array}$ & $\begin{array}{l}10.5(4) \\
=70 \%(26.7 \%)\end{array}$ & $\begin{array}{l}42.5(24.3) \\
=77.3 \%(44.2 \%)\end{array}$ & Pass \\
\hline D & $\begin{array}{l}16.5(12.3) \\
=66 \%(49.2 \%)\end{array}$ & $\begin{array}{l}8.5(7) \\
=56.7 \%(46.7 \%)\end{array}$ & $\begin{array}{l}8.5(4.8) \\
=56.7 \%(32 \%)\end{array}$ & $\begin{array}{l}33.5(24) \\
=60.9 \%(43.6 \%)\end{array}$ & Fail \\
\hline E & $\begin{array}{l}19(11) \\
=76 \%(44 \%)\end{array}$ & $\begin{array}{l}11(6.3) \\
=73.3 \%(42 \%)\end{array}$ & $\begin{array}{l}11.5(5.3) \\
=76.7 \%(35.3 \%)\end{array}$ & $\begin{array}{l}41.5(22.5) \\
=75.5 \%(40.9 \%)\end{array}$ & Pass \\
\hline F & $\begin{array}{l}18.5(11.8) \\
=74 \%(47.2 \%)\end{array}$ & $\begin{array}{l}10(3.5) \\
=66.7 \%(23.3 \%)\end{array}$ & $\begin{array}{l}11(4.3) \\
=73.3 \%(28.7 \%)\end{array}$ & $\begin{array}{l}39.5(19.5) \\
=71.8 \%(35.5 \%)\end{array}$ & Pass \\
\hline G & $\begin{array}{l}15.5(11) \\
=62 \%(44 \%)\end{array}$ & $\begin{array}{l}8(4.3) \\
=53.3 \%(28.7 \%)\end{array}$ & $\begin{array}{l}8.5(3.8) \\
=56.7 \%(25.3 \%)\end{array}$ & $\begin{array}{l}32(19) \\
=58.2 \%(34.5 \%)\end{array}$ & Fail \\
\hline $\begin{array}{l}\text { Group } \\
\text { average }\end{array}$ & \begin{tabular}{l}
$75.1 \%(49.4 \%)$ \\
\hline
\end{tabular} & $\begin{array}{l}65.7 \%(40 \%) \\
68.6 \%(30.2 \%)\end{array}$ & $\begin{array}{l}70.8 \%(41.2 \%) \\
\end{array}$ & \\
\hline
\end{tabular}


TABLE 8

Results of final examination (on-campus group)

\begin{tabular}{|c|c|c|c|c|c|}
\hline Student & $\begin{array}{l}\text { Dialogue } \\
/ 25\end{array}$ & $\begin{array}{l}\text { English Passage } \\
/ 15\end{array}$ & $\begin{array}{l}\text { Mandarin } \\
\text { Passage /15 }\end{array}$ & $\begin{array}{l}\text { Total } \\
155\end{array}$ & $\begin{array}{l}\text { Result } \\
\text { Pass/Fail }\end{array}$ \\
\hline A & $\begin{array}{l}19(15.3) \\
=76 \%(61.2 \%)\end{array}$ & $\begin{array}{l}10.5(7.8) \\
=70 \%(52 \%)\end{array}$ & $\begin{array}{l}10.56 .8) \\
=70 \%(45.3 \%)\end{array}$ & $\begin{array}{l}40(29.8) \\
=72.7 \%(54.2 \%)\end{array}$ & Pass \\
\hline B & $\begin{array}{l}18(16.3) \\
=72 \%(65.2 \%)\end{array}$ & $\begin{array}{l}9(5.5) \\
=60 \%(36.7 \%)\end{array}$ & $\begin{array}{l}10.5(5.5) \\
=70 \%(36.7 \%)\end{array}$ & $\begin{array}{l}37.5(27.3) \\
=68.2 \%(49.6 \%)\end{array}$ & Fail \\
\hline $\mathrm{C}$ & $\begin{array}{l}18(15.3) \\
=72 \%(61.2 \%)\end{array}$ & $\begin{array}{l}8.5(5.3) \\
=56.7 \%(35.5 \%)\end{array}$ & $\begin{array}{l}9(5) \\
=60 \%(33.3 \%)\end{array}$ & $\begin{array}{l}35.5(25.5) \\
=64.5 \%(46.4 \%)\end{array}$ & Fail \\
\hline $\mathrm{D}$ & $\begin{array}{l}20.5(12) \\
=82 \%(48 \%)\end{array}$ & $\begin{array}{l}11(7.3) \\
=73.3 \%(48.7 \%)\end{array}$ & $\begin{array}{l}12(5.3) \\
=80 \%(35.3 \%)\end{array}$ & $\begin{array}{l}43.5(24.5) \\
=79.1 \%(44.5 \%)\end{array}$ & Pass \\
\hline$E$ & $\begin{array}{l}21(12.5) \\
=84 \%(50 \%)\end{array}$ & $\begin{array}{l}10.5(6) \\
=70 \%(40 \%)\end{array}$ & $\begin{array}{l}10.5(5.3) \\
=70 \%(35.3 \%)\end{array}$ & $\begin{array}{l}42(23.8) \\
=76.4 \%(43.3 \%)\end{array}$ & Pass \\
\hline $\mathrm{F}$ & $\begin{array}{l}15(11) \\
=60 \%(44 \%)\end{array}$ & $\begin{array}{l}8(5.3) \\
=53.3 \%(35.3 \%)\end{array}$ & $\begin{array}{l}9.5(4.8) \\
=63.3 \%(32 \%)\end{array}$ & $\begin{array}{l}33(21) \\
=60 \%(38.2 \%)\end{array}$ & Fail \\
\hline $\mathrm{G}$ & $\begin{array}{l}17.5(11) \\
=70 \%(44 \%)\end{array}$ & $\begin{array}{l}8.5(5.3) \\
=56.7 \%(35.3 \%)\end{array}$ & $\begin{array}{l}9.5(4) \\
=63.3 \%(26.7 \%)\end{array}$ & $\begin{array}{l}35.5(20.3) \\
=64.5 \%(36.9 \%)\end{array}$ & Fail \\
\hline $\begin{array}{l}\text { Group } \\
\text { average }\end{array}$ & 73.7\% (53.4\%) & $62.9 \%(40.5 \%)$ & $68.1 \%(34.9 \%)$ & $69.3 \%(44.7 \%)$ & \\
\hline
\end{tabular}

The results show that both the off-campus and on-campus students improved significantly after training, which is reflected in the similar pass rate and similar group average results for the different parts of the test. This indicates that in terms of interpreting per se, the off-campus students achieved a level that was similar or comparable to that of the on-campus students. It was noted that in the pre-training test (cf. Table 6), the average performance of the on-campus students was slightly better than that of the off-campus students. However, in the final examination the off-campus students performed marginally better than the on-campus students.

After the training, five students from each group sat the annual NAATI test. With the students' permission, their results are shown in the following table, with their final examination marks in italics in brackets for comparison. The same letter is used here for each student as before. Due to the limited space in the table, the different test items are indicated as follows:

Dialogue 1: D1

Dialogue 2: D2

Cultural and Social Aspects: $\quad$ C\&S

Ethics of the Profession: E

Passage 1 (consecutive interpreting from Mandarin into English): P1

Passage 2 (consecutive interpreting from English into Mandarin): $\quad$ P2

TABLE 9

Results of the NAATI test for five off-campus students

\begin{tabular}{|l|l|l|l|l|l|l|l|l|}
\hline Student & D 1 /25 & D 2 /25 & C\&S /10 & E /10 & P1/15 & P2/15 & $\begin{array}{l}\text { Total } \\
\text { Marks } / 100\end{array}$ & Result \\
\hline B & 21.5 & 20 & 7 & 7 & 12 & 12.5 & $80(82.7)$ & Pass \\
\hline C & 20 & 19 & 6.5 & 6.5 & 11 & 11 & $74(77.3)$ & Pass \\
\hline D & 16 & 16 & 5.5 & 5.5 & 8 & 8 & $59(60.9)$ & Fail \\
\hline E & 20 & 19.5 & 6.5 & 6.5 & 10.5 & 10.5 & $73.5(75.5)$ & Pass \\
\hline F & 19.5 & 17 & 6 & 5.5 & 9 & 9.5 & $66.5(71.8)$ & Fail \\
\hline
\end{tabular}


Three off-campus students passed the test. The pass rate was $60 \%$, which was comparable to the rate of $57.1 \%$ in the students' final examination. The total mark for each student in the NAATI test was comparable to that in the final examination, apart from Student F, who received a borderline pass in the final examination with a total mark of $71.8 \%$, but only scored $66.5 \%$ in the NAATI test.

Table 10 shows the results of the five on-campus students in the NAATI test.

TABLE 10

Results of the NAATI test for five on-campus students

\begin{tabular}{|l|l|l|l|l|l|l|l|l|}
\hline Student & D 1 /25 & D 2 /25 & C\&S /10 & E /10 & P1/15 & P2/15 & $\begin{array}{l}\text { Total } \\
\text { Marks } \\
/ 100\end{array}$ & Result \\
\hline A & 20.5 & 18 & 6 & 5.5 & 11.5 & 10.5 & $71.5(72.7)$ & Pass \\
\hline B & 19 & 16.5 & 6 & 6 & 9 & 10 & $66.5(68.2)$ & Fail \\
\hline C & 17 & 16 & 5.5 & 5 & 9.5 & 9.5 & $62.5(64.5)$ & Fail \\
\hline E & 21 & 17 & 7 & 6 & 10.5 & 10.5 & $72(79.1)$ & Pass \\
\hline G & 17.5 & 18.5 & 5 & 6 & 7 & 8 & $62(64.5)$ & Fail \\
\hline
\end{tabular}

Two on-campus students passed the test. The pass rate was $40 \%$, which was also comparable to the rate of $42.9 \%$ in the final examination. The total mark for each on-campus student in the test was also comparable to that in the final examination, apart from Student $\mathrm{E}$ who performed better in the final examination.

This indicates that, generally speaking, most of the off-campus and on-campus students who sat the NAATI test demonstrated a similar performance to that in their final examination. It is natural that certain students would perform differently in the final examination and the NAATI test, for reasons such as stress levels, not being familiar with a particular topic, and personal factors on the exam day.

The results of the pre-training test, the final examination and the NAATI test show that the students in both off-campus and on-campus groups had improved significantly after training, and that the interpreting competence achieved by the off-campus students was comparable to that attained by the on-campus students.

\subsection{Technical points}

It was found in a pilot study that a handset telephone was not comfortable or convenient to use in telephone interpreting and that a cordless or mobile phone could cause significant interference (Ko 2006b). The off-campus students were therefore advised to use speakerphones or telephones with headphones. However, during the first three weeks five students did not have such telephones, and the same problems were experienced. Once they had changed to speakerphones the above problems disappeared. The findings have therefore confirmed that not using the appropriate telephone equipment for interpreting can interfere with an interpreter's performance, which partly explains why the off-campus students performed less satisfactorily than the on-campus students in the pre-training test.

When conducting a class via teleconferencing, the teacher rang the first student, and put him/her on hold when he/she answered, then rang the next student, and so on. When the last student came online, the teacher pressed the teleconferencing button on the Polycom to connect all the students and began the class. There were 
four factors that could affect a smooth connection, cause delay or interrupt the class. Firstly, students could arrive late; secondly, they might move away from the telephone after being connected; thirdly, students might lose the connection in the middle of the class - e.g., by accidentally pressing the disconnect button; and fourthly, they might not return to class in time after a break. To solve the first and third problems, the teacher needed a spare telephone such as a mobile phone so that students could ring the teacher for connection or reconnection. To solve the second and fourth problems, strict rules needed to be established for all students to remain online and return to class in time after breaks. The break time needed to be set out clearly, and after each break, the teacher needed to check that all students were online. In the initial weeks, it sometimes took up to 10 minutes to get all students online.

Background noise is another problem that affects the technical environment for remote interpreting (e.g., Fors 1999; Macleod 2002). In this remote training program, background noise came from two sources - the surrounding environment and students' interpreting practice. Noise from the former source includes children crying, and people talking, watching TV, washing dishes, or moving furniture. It took a couple of weeks for the students to experience these problems and take measures to control the noise factor.

It was impossible to eliminate the noise of the other students' interpreting practice. In order to minimize the mutual interference during interpreting, the students were advised to press the "mute" button on their speakerphone, or to turn away from the microphone or simply distance themselves a little from it so that their voice was either cut off or became softer. This was not an ideal solution, but it seems that the students were not overly distracted by this noise. In the questionnaire at the end of the training, they commented that they were not adversely affected by the noise of other students' interpreting because they were concentrating on their own interpreting, and as long as the background noise of other students' interpreting was not very loud it did not distract them. In fact, this kind of background noise also exists in oncampus training in the language laboratory when headphones are used. Since it is a class practice, it is natural that there will be a certain level of mutual interference.

One point worth noting is that during the course of the training program one student traveled to another city in Australia and another to Shenzhen in China. The students informed the teacher of their new telephone numbers before the class. The communication with the student in Australia was very clear. The student in China was connected using a telephone card that provided telecommunication via the Internet. The sound quality was slightly less satisfactory and there was a minor time delay and some background noise. It is believed that if a better connection network or a standard telephone line were used, the quality would improve.

\subsection{Pedagogical issues}

Teaching interpreting via teleconferencing does not provide any live visual interaction with students, making such teaching different from face-to-face teaching in a number of respects. The following subsections will discuss some major issues encountered in this study. 


\subsubsection{Concentration span}

Due to the lack of visual interaction in remote interpreting, problems relating to poor concentration, being under stress and feeling tired easily have been reported by a number of researchers (e.g., Kurz 1999; Fors 1999; Mouzourakis 1996; Moser-Mercer 2003). Some of the claims made are that remote interpreting is more stressful and fatiguing than face-to-face interpreting and should therefore be restricted to shorter time periods such as 10-20 minutes (e.g., Kurz 1999) and be performed by the most competent interpreters. I have argued elsewhere (Ko 2006b) that such issues relate to a lack of specific training in remote interpreting and that a true evaluation must be based on long-term empirical studies rather than on a hands-on trial experience or observation. For instance, in Kurz's experiment, subjects were asked to provide a simultaneous interpretation of a 20 -minute lecture by videoconferencing and 10 minutes in a sound-only situation. Fors' findings were based on observations by a service provider, service user and the interpreter. Moser-Mercer's experiment was based on simultaneous interpreting for a live meeting that lasted for three days. I believe that longer-term empirical studies are necessary to justify such claims. However, it must also be pointed out that the claims made by other researchers mostly relate to simultaneous interpreting, and may therefore not be applicable to liaison interpreting.

It was found in this teaching experiment that during the first three weeks, only one student (14.3\%) in the off-campus group could concentrate for over 30 minutes. It took as long as 6 weeks (or 18 hours) for the majority of students (5 students or $71.4 \%$ ) to become accustomed to this form of interpreting for a period of 45-60 minutes. This also confirms the findings of the pilot study (Ko 2006b). From Week 7, the number reached $6(85.7 \%)$ and remained unchanged until the end of the program. In other words, not all students could achieve a concentration span of 45-60 minutes. This means that there may be a small number of people who feel uncomfortable with this mode of interpreting. The on-campus students did not automatically achieve a concentration span of 45-60 minutes in the first week either. It took 4 weeks (or 12 hours) for 5 students (71.4\%) to achieve a concentration span of 45-60 minutes. It was not until Week 7 that all of the on-campus students were able to concentrate for 45-60 minutes.

These findings suggest that the off-campus students only suffered from a shorter attention span in the initial stages of training when they were not accustomed to working with teleconferencing and the telephone and therefore found it hard to concentrate properly and became tired easily. This also helps to explain why the off-campus students performed less satisfactorily in the pre-training test than the on-campus candidates but achieved a similar level of competence in the final examination. After a period of training, the students were able to gradually overcome this problem. This suggests that time needs to be allowed for off-campus students to familiarize themselves with the equipment and environment.

The findings of this study differ from some claims made by the above-mentioned researchers. For instance, the short experiments described by Kurz fell exactly within the period of time when students had the lowest level of performance. It is therefore natural that the interpreters in these experiments would have felt tired, stressed and frustrated. The findings also suggest that remote interpreters do not necessarily need 
to be the most competent interpreters. The off-campus students were not specifically selected for their outstanding interpreting competence during the intake test, but were ordinary students. Therefore, based on the findings of this empirical research, it can be concluded that a distance interpreting program should last for at least 6 weeks or 18 hours to enable the students to get used to the new learning environment, develop a satisfactory concentration span of around 45 minutes in interpreting practice and overcome their feelings of fatigue and stress. A distance interpreting program shorter than 6 weeks or 18 hours may therefore not be effective.

\subsubsection{Use of person}

One significant aspect of remote teaching and interpreting is use of person, e.g., the first person or the third person. From their experiments on the interpreting of telephone dialogues, Oviatt and Cohen (1992) suggest that telephone interpreters tend to refer to the speakers in the third person and the interpreter him/herself in the first person. In this research, it was found that when raising questions and participating in discussions, students should first identify themselves. For instance, instead of saying "I have a question," the student should say "Tina has a question" and then either go on to say "I don't know how to interpret ...," or continue in the third person by saying "Tina does not know how to interpret..." If this is not done the other participants in the teleconference will not know who is speaking. However, in interpreting practice, the students can interpret in either the first or third person. As long as they remain consistent, it will not cause confusion.

It was also found that private discussions among off-campus students during teleconferencing were almost impossible, because teleconferencing allowed only one person to speak at a time and anything that was said was heard by everyone. This could be considered an advantage over on-campus teaching, in which students may engage in private discussions unrelated to the lesson.

\subsubsection{Teaching dialogue interpreting}

Two forms of dialogue interpreting practice were used in this training - multiple group practice and whole class practice by listening to audio tapes of pre-recorded dialogues. With regard to multiple group practice, because it was impossible to have more than one group of students practice dialogue interpreting concurrently using teleconferencing, the class needed to be split up: one group would use the teleconferencing facility while the other students disconnected from the teleconferencing and used their own three-way conversation facility on their normal telephone to practise dialogue interpreting among themselves. The teacher always stayed with the group that used the teleconferencing facility. In multiple group practice via teleconferencing, since only one student was interpreting, it was very easy for the teacher to monitor the student's practice, provide feedback and make comments. The students found it very effective and helpful, because the teacher could provide individual feedback.

In the multiple group practice by telephone among the students, the students were asked to take turns to be the speakers and the interpreter in the dialogue and to follow up with a discussion. When the group practice finished, the students were 
connected into teleconferencing for a whole-class discussion. Technically speaking, there were no problems for the students using the three-way conversation facility to practice dialogue interpreting by telephone. However, the teacher needed to specify the practice time clearly before the class was broken up into groups so that the students would know when to stop practice and wait to be re-connected to the teleconferencing.

By comparison, in the on-campus group, the teacher could move around from one group to another to observe or give comments as necessary, or to participate as a speaker. This mobility enabled the teacher to have a broad overview of the students' overall practice, provide feedback to different groups, and collect information about the problems encountered by the students. This was not possible with the off-campus group. Although it can be argued that in the on-campus teaching, when the teacher moved to another group the first group was left alone, and the issue of lack of monitoring also arose, generally speaking the issue was much less evident than it was in off-campus teaching.

Whole class practice by listening to audio tapes of pre-recorded dialogues was designed to involve all students in interpreting practice. In the on-campus teaching in the language laboratory, this was straightforward and convenient. The teacher had a control panel in front of him and if he wanted to monitor a student, he simply pressed a button on the control panel. The student was not aware that the teacher was listening to him/her. The teacher could also talk to the student individually without disturbing the others. In addition, the teacher could switch from one student to another. The whole monitoring process was smooth. However, the situation was complicated by teleconferencing. It would have been very messy if all students had interpreted at the same time. In order to solve this problem and minimize mutual interference, the students were asked to press the "mute" button on their telephone set or turn away from the microphone while interpreting so that their voice was softer. If the teacher wanted to monitor a student's interpreting, he had to inform this student before the interpreting segment commenced, so that this student did not have to take any measures to cut off the sound or soften his/her voice. In this case, the teacher could hear the student very clearly - it was just like listening to someone on the telephone. However, if the teacher spoke to this student, all of the other students could hear his comments. In addition, with the equipment used in this experiment, it was impossible for the teacher to switch from one student to another for monitoring or checking. A further disadvantage was that the student might feel nervous and perform less satisfactorily when he/she knew that the teacher would be monitoring his/her interpreting. In general, the monitoring process was not as smooth as in the language laboratory.

\subsubsection{Teaching consecutive interpreting}

In consecutive interpreting practice, students interpreted in one language direction only. Basically, only one type of practice was used in teaching - whole class practice. Pair practice was only used for homework. The whole class practice in consecutive interpreting was very similar to the whole class practice by listening to audio tapes in dialogue interpreting, so the problems encountered and the measures taken in off-campus teaching were the same, such as the students pressing the "mute" button 
while interpreting and the teacher informing the student in advance if he wanted to monitor him/her.

Although pair practice was only used for homework, it has had enormous benefits for the off-campus students and therefore warrants detailed discussion. Pair practice required two students to work together, one delivering passages for the other to interpret. When one student was interpreting, the other student listened and checked for accuracy. At the end of the practice, the students discussed the performance and then swapped roles. The two students in each pair had to arrange a mutually convenient time for practice. The exercise materials were provided by the teacher. For the off-campus group, the practice was conducted by telephone, while for the on-campus group the students could practice face-to-face or by telephone, but no information or training regarding working over the telephone was provided.

The off-campus students unanimously agreed that pair practice was the second most effective form of practice, following the practice in class where the teacher was present. Indeed, there are a number of significant advantages to this form of practice from both learning and teaching perspectives. Pair practice involves live and direct interaction with the speaker. The feedback is also immediate and directly relevant to the interpreting practice. It is similar to real interpreting situations in which a live speech is given. It is convenient, as it only involves two people. The time for practice is flexible, as it can be done at any time, and it is easy to arrange because there are very few technical restrictions. It is easy to manage the level of difficulty because segments delivered for interpreting practice can be long or short and the speed can be fast or slow, depending on the level of competence of the students. In addition, pair practice is easy for the teacher to prepare. The teacher only needs to choose passages of an appropriate level and send them to the students without the need for recording that is required for audio or video interpreting tapes. It is an excellent peer learning exercise for distance teaching.

As for the on-campus students, in the beginning around half of the group did pair practice face-to-face, with one student traveling to the other student's home for practice. However, they soon found this inconvenient and inefficient due to the traveling time involved. In the end, the on-campus students also did their pair practice by telephone. However, it is interesting to note that pair practice was not highly rated by the on-campus students. The results of the questionnaire to the on-campus students regarding this issue show that more than half the students felt that it was even not as effective as individual interpreting practice by listening to audio tapes. They felt that pair practice by telephone was uncomfortable, inconvenient, ineffective and awkward. From the students' comments, it was found that not being accustomed to interpreting over the telephone and not using an appropriate telephone device were the main reasons for their criticism of this form of practice. Pair practice by telephone required these students to change their learning habits and work in a new learning environment. It was therefore natural that they would feel that interpreting by telephone was awkward. This also supported the earlier findings that it took time for students to become accustomed to interpreting by telephone.

The sharply divergent views on the effectiveness of pair practice between the offcampus and on-campus students suggest that the teaching of interpreting by distance mode is different from face-to-face teaching and should therefore be treated in its own right so that methods that are effective for off-campus teaching can be used. 


\subsubsection{Teaching sight translation}

As with consecutive interpreting, only whole class practice was used in class teaching, while pair practice was used for homework. The problems encountered and strategies employed in off-campus teaching were similar to those in teaching consecutive interpreting, with the exception that in sight translation, print materials needed to be provided to students before the exercise began. How to distribute these materials posed some difficulties.

With sight translation, students were supposed to read the text only a couple of minutes before the practice. This means that ideally the students should not receive the text a long time in advance. In this program, two students $(28.6 \%)$ had two telephone lines and were therefore able to receive the text either by fax or through First Class while remaining on line for teleconferencing. For the other five students, the materials were placed in a separately-sealed envelope and sent by mail. The students were asked not to open the envelope until they were instructed to do so in class, but this could not be guaranteed. It is worth noting that nowadays the advances of telecommunications technologies have made it possible to use one normal telephone line for both Internet access and telephone calls such as Asymmetric Digital Subscriber Line (ADSL).

The feasibility and effectiveness of using First Class in delivering sight translation materials was tested by these two students. It was found that although these students were able to receive texts sent by the teacher via First Class during the class, they complained that it was inconvenient and inefficient to use the screen for doing sight translation. For instance, they could not write on the screen and needed to scroll up and down the screen while doing the sight translation. In their reading time before doing a sight translation, students usually need to write notes or symbols, or look up words in dictionaries. It was inconvenient and time-consuming to do this on the screen. According to Nielsen (1996), reading on computer screens reduces the reading speed by $25 \%$ compared to reading from paper. The students' efficiency and performance in sight translation were therefore affected by the above factors, and in the end they chose to print out the text. Pedagogically, sending the materials via the Internet was to ensure that the students only received the materials a short time before the exercise. However, there were more disadvantages in using the Internet and computer than in using conventional printed materials. This also means that even when the modern ADSL technology is used, similar problems will be experienced.

\subsubsection{Development of paralinguistic skills}

Paralinguistic skills include maintaining an appropriate level of eye contact, demonstrating proper body language and appropriately managing interpreting situations. Paralinguistic skills are important in interpreting because they help facilitate smooth communication and avoid misunderstandings in interpreting (e.g., Wadensjö 1992; Roy 2000; Gentile et al. 1996; Ko and Lin 1996; Poyatos 1987; Riccardi 2002). The development of paralinguistic skills was included in this program to assess whether students trained in circumstances in which no visual interaction was possible could demonstrate and effectively use appropriate paralinguistic skills in face-to-face interpreting. 
Paralinguistic skills were taught to both groups of students. For instance, it was explained and emphasized that while interpreting they should maintain an appropriate level of eye contact with the speakers. They should not bend over their notes or use inappropriate body language. They should also manage the interpreting situation properly, such as handling interruptions by the speaker in the middle of their interpreting. A videotape on paralinguistic skills was played to the on-campus students in class, while a copy of the tape was sent to each off-campus student to watch by him/herself. This was followed by a discussion in class, in order to give the students an understanding of how poor paralinguistic skills could hamper interpreting and good skills could facilitate communication.

Few problems were experienced in teaching the on-campus group. The teacher was able to demonstrate paralinguistic skills, point out problems and discuss them in class. However, teaching paralinguistic skills by distance mode presented a much greater challenge, because of the lack of face-to-face interaction. It was found that from the perspective of off-campus teaching, paralinguistic skills could be divided into two categories - i.e., skills relevant to verbal communication and skills associated with visual interaction. The former involve seeking clarification and management of interpreting situations. For instance, in a dialogue situation, if the interpreter does not understand a term and needs to seek clarification from the speaker, he/she can ask the speaker for an explanation or paraphrase by saying "Could you please explain..." or "What do you mean by...?" If the interpreter is cut short by the speaker before he/she finishes, the interpreter can say "Excuse me but I have not finished interpreting." These issues are associated more with verbal interaction than with visual interaction, and can therefore be adequately dealt with through verbal communication.

Paralinguistic skills associated with visual interaction involve body language and eye contact. For instance, in face-to-face interpreting, the interpreter should not bend over his/her notes for a long time or look at the ceiling while interpreting, but should maintain an appropriate level of eye contact with the speaker. Teaching and monitoring these skills in the off-campus students was difficult. It was practically impossible for the teacher to give a live demonstration of such skills or observe the students' performance and provide feedback. It was also difficult for the students to practice such skills over the telephone. For example, it was unrealistic to ask the students to maintain proper seated posture, demonstrate appropriate body language and keep eye contact (with nobody) while they were interpreting. The teacher could only emphasize the importance of paralinguistic skills, raise cases to illustrate these points, and constantly remind students of such skills. In the post-training interview, two students suggested that photos of the teacher and fellow students be distributed among the class at the beginning of the program so that the students could "see" the teacher and fellow students when interpreting. This is a point worth considering in future training programs.

In the live face-to-face dialogue interpreting test, two on-campus students experienced some problems. Specifically, as noted by the teacher, one student was "over expressive in paralinguistic aspects, e.g., laughing by herself while neither of the speakers cracked a joke or laughed," and another student was "bending over notes while listening and interpreting, and not maintaining regular eye contact." 
However, more problems were identified in the off-campus group. The following are the teacher's observations about the paralinguistic skills of these five students in face-to-face interpreting.

Student 1: "Bending over notes while interpreting and waiting a long time to start interpreting after a dialogue segment was delivered."

Student 2: "Over expressive in body language at the beginning - i.e., maintaining eye contact with the speaker even while taking notes, but no more later."

Student 3: "Bending over notes at the beginning, but improved later."

Student 4: "Forgot the note book, hence had to totally rely on memory."

Student 5: "Bending over notes in the middle of interpreting, but fine otherwise."

This indicates that five students (71.4\%) experienced some problems with paralinguistic skills, and that these problems were all related to visual interaction. Among the five students, three had the problem of bending over their notes while interpreting. However, it was noted that most of these problems were not persistent in the interpreting process - the students soon became aware of these problems and rectified them. That one student forgot to take a notebook to the interpreting test might indicate that this student was accustomed to interpreting when sitting at her office/ study desk where she could easily have access to a notebook or paper. Apart from the above problems, the students' paralinguistic skills were acceptable and satisfactory. The students' poor performance, though not persistent, reflected the impact of the lack of face-to-face interaction in teaching and interpreting practice. It is believed that with more exposure to face-to-face interpreting, the students' paralinguistic skills would improve.

\subsection{Evaluation of teaching workload}

The following table shows the total amount of time spent on different items for each group.

TABLE 11

Teaching workload

\begin{tabular}{|l|l|l|}
\hline Item & $\begin{array}{l}\text { Off-campus group: } \\
\text { Hours per week }\end{array}$ & $\begin{array}{l}\text { On-campus group: } \\
\text { Hours per week }\end{array}$ \\
\hline Teaching & 3 & 3 \\
\hline Consultation & 1 & 1 \\
\hline Preparation of teaching materials & 1 hour and $16 \mathrm{~min}$. & 1 hour and $16 \mathrm{~min}$. \\
\hline Checking students' homework & 1 & 1 \\
\hline Administration & 2 hours and 41 min. & 1 hour and $18 \mathrm{~min}$. \\
\hline Total & 8 hours 57 min. & 7 hours and 34 min. \\
\hline Final examination & 6 hours (not weekly) & 6 hours (not weekly) \\
\hline
\end{tabular}

Since teaching was conducted based on the principle that the content and amount of training for the two groups were identical except for different methods of delivery, the time spent on a number of items was fixed and therefore identical. Preparing of teaching materials includes selection and preparation of teaching materials for dialogue interpreting, consecutive interpreting and sight translation, recording dialogues and consecutive interpreting passages, selection of reading materials on interpreting 
theory and techniques, and selection and preparation of homework materials. The workload in this category could not be calculated separately for each group because it was shared between the two groups. In addition, the teacher had a databank of teaching materials from previous years of teaching. Only around 30\% of the materials were newly prepared. The preparation took a total of 33 hours for both groups. The average number of hours per week per group was therefore $33 \div 13 \div 2=1.27$, which was equivalent to 1 hour and 16 minutes. However, even if there had been only one group to be taught, the same amount of time - 33 hours - would have been required.

Weekly interpreting homework was designed to keep the students in practice and encourage peer learning. The teacher only checked the homework submitted by the students to make sure that they had done it, but could choose to listen to one or two students' tapes in each group each week. The amount of time spent for each group was equal - i.e., one hour.

Administration is the only item that differed significantly between the two groups in terms of workload. The items of the administration work for the two groups are as follows:

\section{TABLE 12}

\section{Administration work for both groups}

\begin{tabular}{|l|l|}
\hline Administration for off-campus group & Administration for on-campus group \\
\hline - Writing course outline & - Writing course outline \\
- Photocopying & - Photocopying \\
- Duplicating audio and video tapes & - Duplicating audio and video tapes \\
- Answing to students' e-mails & - Replying to students' e-mails \\
- Organizing the final exam including audio & - Answering telephone calls \\
- Ond video recording equipment and staffing & and video recording equipment and staffing \\
- Setting up the teleconferencing facility & \\
- Finding suitable telephone devices & \\
- Helping students connect into First Class & \\
- Sending materials to students by mail or fax & \\
- Returning homework to students by mail & \\
\hline
\end{tabular}

Some items were identical for both groups, but the off-campus group had many additional items. Administration work was often done in bits and pieces, and it was difficult and sometimes impractical to time precisely - for instance, replying to emails and answering telephone calls. An effort was made to record the time as closely as possible.

\section{TABLE 13}

\section{Time spent on administration by weeks}

\begin{tabular}{|l|c|c|c|c|c|c|c|c|c|c|c|c|c|}
\hline Week & 1 & 2 & 3 & 4 & 5 & 6 & 7 & 8 & 9 & 10 & 11 & 12 & 13 \\
\hline Hours for off-campus group & 8 & 3 & 2 & 2.5 & 2 & 2 & 1 & 1.5 & 1.5 & 3 & 2.5 & 2 & 4 \\
\hline Hours for on-campus group & 3 & 1.5 & 1 & 1 & 1 & 1 & 0.5 & 1 & 1 & 2 & 1.5 & 1 & 1.5 \\
\hline
\end{tabular}

The administration work for the on-campus group took a total of 17 hours, or 1 hour and 18 minutes per week on average, while the administration work for the 
off-campus group was 35 hours, or 2 hours and 41 minutes per week. The administration time for the off-campus group was more than twice that for the on-campus group. This finding is in line with the overall situation with distance education, as distance education requires much more preparation time than traditional education (Schlosser and Anderson 1994). For instance, the amount of time required to distribute materials to the on-campus students in the language laboratory was almost negligible, but a fairly large amount of time was needed to do the same thing for the off-campus students, including wrapping tapes with foam sheet if necessary, writing envelopes and sending by mail. It was also found that the items that took a large amount of time on a weekly basis for the off-campus group related to duplicating audio and video tapes and photocopying, which was largely related to the provision of homework. In other words, if no homework was provided, the amount of administration work could be greatly reduced. The administration workload for the offcampus group was particularly heavy at the beginning and the end of the program. At the beginning, a large quantity of material had to be prepared, photocopied and sent to the students to ensure that they had a clear understanding of how the course would be conducted and how to use the relevant facilities, while at the end of the program, proper preparation and arrangements needed to be made for the final examination.

\subsection{Evaluation of cost effectiveness}

For the purpose of this experiment, the training was provided free of charge. The students did not pay any tuition, nor did they pay for the use of major facilities such as teleconferencing and the language laboratory. The researcher also had access to some facilities such as a photocopier and the Internet for free. The costs would be different if these conditions change. In addition, some equipment such as audio cassette players is of lasting value, even if it needs to be purchased. Therefore, the cost evaluation only involved those items that were relevant and were able to be calculated, particularly the running costs, such as the cost of teleconferencing and telephone calls. There are two categories of costs - i.e., costs for the educational institution and costs for students.

\subsubsection{Costs for the educational institution}

The most important and relevant facilities and costs for the off-campus teaching were the Polycom, teleconferencing and postage. Although the Polycom was provided by the university where the researcher worked, the cost to purchase a Polycom is about AUS $\$ 300.00$ (Australian Dollars). There are, however, other brands of teleconferencing equipment on the market that have similar features and functions, such as Panasonic at a cost of AUS $\$ 195.00$ (quoted by a Telstra Shop in Melbourne, Australia on 5 July 2006).

The teleconferencing facility was provided to the university by Telstra, a telephone company in Australia, as an inherent feature of the telephone exchange system of Private Automatic Branch Exchange (PABX) at no extra cost. The users only need to pay for the cost of telephone calls at the normal rate. When the program was conducted in 2003, the rate for a local call for a business line was AUS\$0.16. 
Telstra also provided a capped interstate rate of AUS $\$ 2.50$ for three hours, 24 hours a day, seven days a week. In the off-campus group, there were three students living in the metropolitan area of Melbourne, three students in Sydney and one in Perth. So the cost of telephone calls for conducting a typical three-hour class by teleconferencing to three local students and four interstate students was: AUS $\$ 0.16 \times 3+$ AUS $\$ 2.50 \times 4=$ AUS $\$ 10.32$. The total cost for the 13-week program was: AUS $\$ 10.32$ x $13=$ AUS $\$ 134.16$. Telstra and some other telephone companies also provide teleconferencing services for commercial purposes, but there are charges for these services (e.g., Telstra 2006).

For on-campus training, the language laboratory was the most important facility, but the running costs such as maintenance related to this program could not be worked out proportionately.

Postage was only a cost item for the off-campus group, and involved sending audio and video tapes and printed materials to students, as well as returning assignments to the students by mail. The total amount of postage for the program was around AUS $\$ 184.00$, or AUS $\$ 26.30$ per student. In this research, no efforts were made to produce electronic copies of teaching materials, including audio and video materials. If such copies were available, the cost of postage could be reduced. For comparison purposes, the actual costs for both groups are listed below:

TABLE 14

Costs for the educational institution

\begin{tabular}{|l|l|l|}
\hline Cost item & Off-campus (in AUS\$) & On-campus (in AUS\$) \\
\hline Running costs for teaching facilities & 134.16 & Not calculable \\
\hline Postage & 184.00 & Not applicable \\
\hline Total & 318.16 & Not applicable or calculable \\
\hline
\end{tabular}

According to this table, the off-campus program costs more than the on-campus program. However it is hard to conclude that the off-campus program is more expensive than the on-campus program because not all costs could be worked out. Given the total running cost of AUS $\$ 318.16$ for a 13-week training program for seven students, it can be concluded that teaching interpreting using teleconferencing is cost effective.

\subsubsection{Costs for students}

The most relevant cost items for the off-campus students were speakerphones, telephone calls and postage. The students already had other equipment and services such as cassette players, computers and the Internet, which could not be costed for this program. The price of a speakerphone varied from AUS $\$ 39$ to $\$ 219$ depending on its features. Finally, all students purchased a DSE brand speakerphone at a cost of AUS\$55.00. It is worth noting that in a formal training program run by educational institutions, it would be worthwhile to provide uniform speakerphones to the students and retrieve them after training, so that if any technical problems occurred, they would be easier to fix.

The off-campus students needed to pay for the cost of calling fellow students for interpreting practice such as pair practice. A local call from a residential line was 
AUS $\$ 0.20$ in 2003. As for interstate calls, students were advised to use the discount long distance telephone call service provided by Digiplus - a telecommunications company. When the program was conducted in 2003, it cost AUS $\$ 1.99$ to call anywhere in Australia for an unlimited call time between 7:00pm and midnight seven days a week (Digiplus 2003). Due to the repackaging of its products by Digiplus, it now costs AUS $\$ 0.99$ to make a call to anywhere in Australia for one hour at any time during the day (Digiplus 2006). A similar product is offered by AAPT - another telecommunications company. It costs AUS $\$ 1.98$ to make a national call for two hours at any time during the day (AAPT 2006).

According to the requirements for attending this program, an off-campus student had to make an average of two telephone calls per week to fellow students for interpreting practice. If it is assumed both calls were STD (long-distance) calls, the average cost would be around AUS $\$ 4.00$ per week or AUS\$52.00 for the 13-week program. Of course, students could make telephone calls for other purposes, e.g., calling the teacher's mobile phone for reconnection during class because they lost the line, or calling the teacher for consultation. The amount of these costs was not significant and was hard to record, and was therefore not analyzed.

The cost of postage related to the off-campus students only. The average cost of postage was around AUS $\$ 2.00$ per student per week, or AUS $\$ 26.00$ for the whole program.

The actual costs for the off-campus and on-campus students were as follows:

TABLE 15

Costs for students

\begin{tabular}{|l|l|l|}
\hline Cost item & Off-campus students (in AUS\$) & On-campus students (in AUS\$) \\
\hline Speakerphone & 55.00 & Not applicable \\
\hline Telephone calls & 52.00 & Not applicable \\
\hline Cost of postage & 26.00 & Not applicable \\
\hline Total & 133.00 & Not applicable \\
\hline
\end{tabular}

The total cost for an off-campus student to attend the 13-week program was around AUS\$133.00. Even though an off-campus student had to spend more on the above items, they did not need to travel. If an on-campus student took public transport to the university to attend classes, a daily pass covering two zones in Melbourne was AUS\$8.20 in 2003. The cost of public transport to attend a 13-week program would therefore be AUS $\$ 8.20$ x $13=$ AUS $\$ 106.60$ - only AUS $\$ 26.40$ less than the cost for an off-campus student. If the time spent on the road could be considered a cost item, it could cost the students more to attend the on-campus program than the offcampus program, especially for those students who live some distance away. From the perspective of the students, learning interpreting by distance mode is therefore cost effective.

\section{Conclusion}

This study has demonstrated that teaching interpreting via sound-only teleconference is feasible both technologically and pedagogically. Students trained by distance mode can achieve a level similar or comparable to that of on-campus students in terms of 
interpreting ability and skills. It is definitely possible for these students to overcome the impact of the lack of face-to-face contact in teaching and learning interpreting. Students can achieve a concentration span comparable to that of face-to-face learning and interpreting, provided they use the proper equipment and undergo a period of specific training. A distance training program should not be too short - specifically not less than 6 weeks or 18 hours - to achieve the desired outcomes. Interpreters trained by distance mode can generally demonstrate the paralinguistic skills required for face-to-face interpreting, but more exposure to interpreting in such settings would be desirable.

Teaching interpreting by distance mode requires at least twice as much administrative work as face-to-face teaching, which should be taken into account in the planning of any interpreter training program by distance mode. However, teaching interpreting by distance mode is cost effective both for the educational institution and the students.

Teaching interpreting by distance mode should be treated as a discipline in its own right, rather than being run in parallel with an on-campus program using identical teaching methods. This is because teaching interpreting by distance mode has certain unique features that affect students' performance in the intake test, program planning and the pedagogical strategies that need to be adopted. In addition, certain forms of practice, such as pair practice, are particularly effective in learning interpreting by distance mode.

This study has certain limitations. Due to the limited capacity of the available teleconferencing facility, only seven students were trained in the off-campus mode. The implications for teaching, class management, administration and overall efficiency of the program may differ if the class size is larger, e.g., 15 students.

This study relied heavily on the sound-only teleconferencing facility and the telephone. Other popular telecommunications technologies have not been sufficiently explored and tested, especially video conferencing via satellite or the Internet. Advances in telecommunications technology may mean that media with the capacity to accommodate both verbal and visual interaction may be more suitable and effective in teaching interpreting by distance mode in future.

This study was conducted in Australia and all participants were living in this country, where telecommunications services are of a uniform standard, the time difference between different areas is only two hours, and the cost of telecommunications including long distance calls is affordable for both educational institutions and students. Furthermore, the researcher had access to many facilities, services and forms of technical support for free. The feasibility of such programs would need to be reassessed if these variables were to change.

Further research is therefore required in these areas, particularly using Internet technologies that feature visual interaction to train more students. As O'Hagan and Ashworth (2002: xii) point out, "[w] ith the convergence of voice and Web progressing with the third generation (3G) mobile technology, we believe that remote interpreting [via the Internet] in one form or another will become a necessity in the near future." This may also happen in the field of interpreter training. 


\section{REFERENCES}

AAPT: <http://www.aapt.com.au/homephone/homechat/index.asp>, accessed May 1, 2006.

CARR, S. and D. G. STEYN (2000): "Distance education training for interpreters - an insurmountable oxymoron?," in Roberts, R. P. et al. (eds.), The Critical Link 2: Interpreters in the Community, Amsterdam, John Benjamin, pp. 83-88.

Deakin University (1996): “Three-cornered Interpreting Assessment Sheet," (unpublished)

Digiplus: <www.digiplus.com.au>, accessed January 3, 2003.

Digiplus: <http://www.digiplus.com.au/DigiHome/digihome_callrates.asp\#national $>$, accessed May 1, 2006.

Fors, J. (1999): “Perspectives on remote public service interpreting," in Helge, H. N. (coord.) "Quality issues in remote interpreting," in LugRIs, A. A. and A. F. OcAmpo (eds.), Anovar/ anosar estudios de tranduccion e interpretacion I, Servicio de Publicacion da Universidade de Vigo, pp. 117-119.

Gentile, A. et al. (1996): Liaison Interpreting - A Handbook, Melbourne, Melbourne University Press.

Intercall Australia Pty Ltd: <www.intercall.com.au>, accessed May 1, 2006.

Ko, L. and Y. L. Lin (1996): Textbook of English-Chinese interpreting, Fujian People's Press, China.

Ko, L. (1998): "Liaison interpreter training on the eve of the 21st century," Proceedings of the 2nd Asian translators' forum, Seoul, Korean Society of Translators, pp. 149-155.

Ko, L. (2006a): “Teaching interpreting by distance mode: Possibilities and constraints," Interpreting 8-1, pp. 67-96.

Ko, L. (2006b): "The need for long-term empirical studies in remote interpreting research: A case study of telephone interpreting," Linguistica Antverpiensia 5, pp. 325-338.

Kurz, I. (1999): "Remote conference interpreting: Assessing the technology," in Helge, H. N. (coord.) "Quality issues in remote interpreting," in Lugris, A. A. and A. F. Ocampo (eds.), Anovar/anosar estudios de tranduccion e interpretacion I, Servicio de Publicacion da Universidade de Vigo, pp. 114-116.

Kuwahata-Rich, M. and Y. SAYeg (1997): "Sight translation for interpreters," Proceedings of eighth international conference on Japanese-English translation and interpreting, Sheffield, pp. 178-185.

Language Line Services: <http://www.languageline.com/home.php >, accessed July 29, 2006.

MACLEOD, H. (2000): "Telephone tutorials in distance learning programmes," < http://www.gla. au.uk/Incs/main/FOURTEEN.HTM>, accessed November 17, 2001.

MAY, T. L. (1996): "Daxue kouyi rumen kecheng yingyizhong shiyi lianxi zhi yunyong yu jiaoxue jianyi" (Sight translation as a tool of training in the undergraduate training for interpretation), Studies of interpretation and translation 1, Taiwan, Translation Research Society of Republic of China, pp. 141-161.

Moeketsi, R. and K. Wallmach (2005): "From sphaza to makoya!: A BA degree for court interpreters in South Africa," Journal for Speech, Language and the Law: Forensic Linguistics 12, pp. 77-108.

Mouzourakis, P. (1996): "Videoconferencing: techniques and challenges," Interpreting 1-1, pp. 21-38.

Moser-Mercer, B. (2003): "Remote interpreting: Assessment of human factors and performance parameters," <http://www.aiic.net/ViewPage.cfm?page_id=1125\#methods>, accessed September 2, 2006.

NAATI (1997): Interpreter and Translator Examiner Manual, (not publicly available).

NAATI (2002): Manual for candidates (1 $9^{\text {th }}$ Edition), Canberra, Author.

Nielsen, J. (1996): "Jakob Nielsen's Alertbox for February 1996: in defence of print," <http:// www.useit.com/alertbox/9602>, accessed November 17, 2001.

O'Hagan, M. and D. Ashworth (2002): Translation-mediated Communication in a Digital World, Clevedon, Buffalo, Toronto, Sydney, Multilingual Matters Ltd. 
Optus: <http://www.optus.com.au/portal/site/personal/menuitem.ded28886f64e13141ff0a1108 c8ac7a0/?vgnextoid $=44 \mathrm{fc} 3 \mathrm{~b} 45 \mathrm{~d} 5554010 \mathrm{VgnVCM} 10000029 \mathrm{a} 67 \mathrm{c0}$ aRCRD\&vgnextchannel $=$ 445c3b45d5554010VgnVCM10000029a67c0aRCRD\&vgnextfmt=default >, accessed May 1, 2006.

Oviatt, S. and P. R. Cohen (1992): "Spoken language in interpreted telephone dialogues," Computer Speech and Language 6, pp. 277-302.

Pointon, T. et al. (1998): TIS in Europe 1976-2001: Determining the Origins, Size, Nature and Outlook of Telephone Interpreting Services in Europe, the Pointon Partnership, England and Deakin University, Australia.

Poyatos, F. (1987): "Nonverbal communication in simultaneous and consecutive interpretation: a theoretical model and new perspectives," in PöchHacker, F. and M. Shlesinger (eds.), The Interpreting Studies Reader, London and New York, Routledge, pp. 234-246.

RICCARDI, A. (2002): "Evaluation in interpreting: macrocriteria and microcriteria," in Hung, E. (ed.), Teaching Translation and Interpreting 4: Building Bridges, Amsterdam/Philadephia, John Benjamins, pp. 115-126.

Rowan, M. (1998): Moving Towards Meaning: Interpreting Techniques, Adelaide Institute of TAFE, Australia.

Roy, C. (2000): Interpreting as a Discourse Process, Oxford University Press.

Schlosser, C.A. and M. L. Anderson (1994): Distance Education: A Review of the Literature, Iowa State University.

Telstra: <www.telstra.com.au/conferlink>, accessed May 1, 2006.

Testra: $<$ http://www.telstra.com.au/products/product.cfm?prod_id=2457\&mode=search\&searc htype=name\&searchtext=3-way\%20conversation $>$, accessed May 1, 2006.

University of Geneva: <www.certificate.eti.unige.ch/training>, accessed September 29, 2005.

U.S. Department of Health and Human Services, <http://www.phppo.cdc.gov/phtn/prime>, accessed November 17, 2001.

WADENSJÖ, C. (1992): Interpreting as Interaction, Linkoping, Linkoping University.

WEBER, W. K. (1989): "Improved ways of teaching consecutive interpretation," in Gran, L. and J. DodDs (eds.), The Theoretical and Practical Aspects of Teaching Conference Interpretation, Udine, Campanotto Editore, pp. 161-166. 